\title{
Climate Smart Agriculture as Final Goal: Use of Improved Cereals Varieties in Cinzana, Mali.
}

\author{
Kalifa TRAORE (Corresponding author) \\ IER, Centre Régional de Recherche Agronomique de Sotuba \\ Laboratoire Sol-Eau-Plante Bp : 262, Bamako, Mali. \\ Tel: 223-7604-7556 E-mail: ibosimon_1@yahoo.fr
}

\begin{abstract}
Daouda SIDIBE
IER, Centre Régional de Recherche Agronomique de Sotuba

Délégation Ressources Forestières, Bp : 262, Bamako, Mali.

Tel: 223-6678-0355Ｅ-mail: dasidibe2011@ hotmail.com

\section{Harouna COULIBALY}

IER, Centre Régional de Recherche Agronomique de Sotuba

Laboratoire Sol-Eau-Plante Bp : 262, Bamako, Mali.

Tel: 223-7649-4023Ｅ-mail: hscoulibaly@yahoo.fr
\end{abstract}

Received: November 2, 2016 Accepted: November 28, $2016 \quad$ Published: January 10, 2017

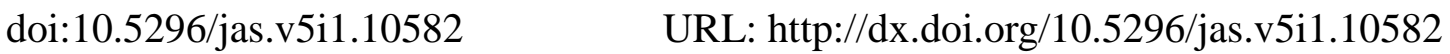

\begin{abstract}
Climate variability and change are recognized as the greatest challenge to crop production and food security in sub-Saharan Africa. This work assesses farmers' perception on the contribution of improved varieties of sorghum and millet in the search for food security in Cinzana rural commune of Mali in the current context of climate change.

The methodology was based on focus group surveys with both, the decentralized technical services, administrative and municipal authorities, NGOs, farmer organizations and producers but also farmer exchanges visits on improved varieties tested in farmer's field.

The result shows that climate change is described by the majority of farmers (87\%) as decrease in rainfall amount and length of rainy seasons, high increases in temperature and
\end{abstract}


high deforestation and water scarcity. Unpredictability of climate, (80\%), drought (70\%) and heavy rain $(65 \%)$ occurrence were identified as major perception of farmers on risks in climate for crop production and soil degradation. After farmers' study tour, $80 \%$ of the participants mentioned a better growth of plants and increase of soil moisture with the use of contour ridges tillage as a water conservation technology. Adapted cycle (55\%) and higher yield (37\%) of improved varieties were farmer's main drivers for adoption of improved millet and sorghum varieties.

The study revealed that local farmers have substantial knowledge on climate variabilities and risks and also are aware of some adaptation strategies. However, for wide scale adoption of effective strategies, capacity strengthening appeared a prerequisite.

Keywords: Climate Change, Food Security, Millet, Sorghum, water conservation

\section{Background}

Global climate change is widely acknowledged (IPCC, 2007) and is considered as posing the greatest challenge to crop production and food security in Sub-Saharan Africa where about 60 percent of the economically active population works in the agricultural sector (WDI, 2006). Agriculture in Sahelian countries is characterized by a strong dependency on rainfall; low use of external inputs such as improved seeds and fertilizers; weak mechanization; and poor linkage to markets (Tacko Kandji et al., 2006). In Mali, Climate change (CC) is expected to have drastic consequences by reduction in cereal yield due to drought and declining soil fertility; reduction of livestock numbers due to the shrinking of grazing areas; reduction of fauna and fishing resources; expansion of cultivated areas to compensate for low yields, if adequate adaptation actions are not taken. This situation is related to vulnerability to climatic changes and very low coping capacity (Nellemann et al., 2009). To adapt to this changing climate characteristics, the government of Mali focuses its adaptation strategies on agro-hydro-meteorological survey of crops and pastures with a view to develop early warning systems; and agro-meteorological assistance to the rural population by providing timely information on weather and useful advise (adapted improved varieties, fertilization etc.) for coping with different scenarios (Tacko Kandji et al., 2006). Globally, the negative impacts of climate change can significantly be reduced if appropriates adaptation practices are adopted.

Millet (Pennisetum spp) and sorghum (Sorghum spp) are the main staple crops in the Sahelian areas of Mali but yields are low with an average yield of $768 \mathrm{~kg} \mathrm{ha}^{-1}$ and $943 \mathrm{~kg} \mathrm{ha}^{-1}$, respectively (FAOSTAT, 2008). In Cinzana commune of Mali , the area under millet was 27,167 ha with a mean yield of $960 \mathrm{~kg} \mathrm{ha}^{-1}$ whereas only 2,533 ha were planted with sorghum with a lower mean yield of $920 \mathrm{~kg} \mathrm{ha}^{-1}$ during the cropping season of 2014 (Goudou et al., 2012; SSAC, 2014). The reasons were for sure related to climate variability but also inherent soil fertility and inadequate management practices (Doumbia et al., 2009).

Warmer and drier conditions (rainfall variability) in the Sahel, have led to a reduced length of growing season with negative effects on farming systems and crops production (Masters and Norgrove, 2010). In fact, shift or variability in annual rainfall which led to radical shift in farming practices, increased frequency of dry spells during the growing season, have incited researchers to introduce or develop new crop varieties to stabilize food production which is a 
central concern of development.

In all of the Sahelian countries, crop varieties and species currently grown by farmers cannot tolerate these heavy constraints. Among several strategies, utilization of adapted improved available and accepted varieties by farmers and water conservation techniques are relevant as climate change adaptation measures. In fact, 20 to 40 percent of annual rainfall is lost as runoff leading some times to severe erosion (Tacko Kandji et al., 2006) and globally only $10 \%-15 \%$ of rainfall will be used by crops for transpiration (Bationo and Buerkert, 2001). To tackle the problem, several, proven soil and water conservations techniques that restore degraded lands and improve water infiltration in the soil (Gigou et al., 2006; Zougmore et al., 2014) and agroforestry technologies that restore soil fertility and control soil erosion were also developed (Bayala et al., 2012) to help farmers adapt to climate change.

Wide adoption of adaptation techniques depend strongly on how farmers distinguish climate change to other natural events i.e. the understanding they have on the issue but also an availability of accessible measures to be undertaken after a climatic event is realized. Kemausuor et al. (2011) reported that, to adapt effectively to climate change, farmers must have true perceptions on climate state and understand future trends. He mentioned that farmers take decisions in the context of their own environment and consequently there is a need to know how climatic factors interact to impact on soil and water resources and crop productivity.

Famers' perceptions of climate variability and change and how these perceptions determine the choice of coping or adaptation strategies and options have been investigated by several studies in West African Sahel to contribute to climatic risk management (Akponikpe et al., 2010).

This study highlights efforts made in Mali by Climate Change Agriculture and Food Security (CCAFS) and International Center for Research in Agroforestry (ICRAF) to fund research activities in the CCAF benchmark sites to improve farmer's livelihoods. This research was based on a multidisciplinary background of stakeholders (farmers based organization, municipality, technical agricultural, livestock and forestry agents, NGOs, agrodealers, etc.) involved in the implementation of the project. Furthermore, previous interdisciplinary studies in the CCAFS sites showed clear evidence that farmers performed various cropping systems to adapt to the specific constraints of their households (Goudou et al., 2012). So, improved varieties of sorghum and millet and water conservation techniques were introduced in the area to help farmers better adapt to this unpredictable Sahelian climate of Cinzana. In the context of sustainable development, this approach was valuable since responding to farmers demands. Furthermore, few studies were performed to gather the views of farmer on the performance of improved sorghum and millet varieties under water conservation technique in sahelian zone of Mali.

This study aimed at better understanding farmer's perception of current climate change and variabilities and strategies implemented or developed for climatic risk management to reduce the negative impact on their cropping systems and livelihoods in Cinzana commune in Mali.

\section{Materials and Methods}




\subsection{Overview of the Study Area}

The research was conducted in the Cinzana commune $\left(13^{\circ} 15^{\prime} \mathrm{N}\right.$ and $\left.5^{\circ} 58^{\prime} \mathrm{W}\right)$ situated in the Sahel region of Mali at $37 \mathrm{~km}$ south-east of the city of Segou. It covers an area of 1,100 $\mathrm{km}^{2}$ and is located in Segou administrative region. The population is estimated at 32,249 inhabitants distributed among 72 villages. The annual rainfalls for the past ten years are in the range of 650 and $750 \mathrm{~mm}$. Subsistence agriculture is the main activity in the commune and millet and sorghum are the most grown crops and cover about $90 \%$ of cultivated areas. The cropping systems encountered are cereals as sole crops or, in intercropping with cowpea, peanut, woandzou etc. Minor crop such as fonio and sesame are also cropped in the area. Millet is grown on sandy soils and sorghum on heavy clay soils (Ejeta et al., 1987; Macauley et al., 2015). Although of subsistence type, part of agriculture products is often sold on the Cinzana weekly market. Livestock breeding is also an important source of income for the families (PROMISAM, 2007). The CGIAR research program Climate Change Agriculture and Food Security (CCAFS) is being implemented in the municipality and covers an area of $30 \mathrm{~km} \times 30 \mathrm{~km}$ which is composed of 46 villages. Seven (7) villages from this CCAFS site, namely Dona, Moussawere, Ngakoro, Tongo, Sorobougou, Djambougou, Dougakoungo were selected for this study.

\subsection{On Farm Experiment on Soil and Water Conservation Technique}

Before the implementation of the project's activities on the ground, two workshops were organized in 2012: the first one at the district level with technical services and NGOs in Segou region, the second at the communal level with agricultural, livestock, forestry and research agents, as well as farmer organizations and producers of the Cinzana area. The aim of these workshops was to identify and validate research and development activities related to climate change adaptation and mitigation in Mali. The outcome of the two workshops was used to develop protocols for on farm trials. In 2012, the experiment started with 3 farmers from each of the 3 villages (Moussawere, Sorobougou, and Ngakoro) testing sorghum (CSM63 and Seguifa) and millet (Toroniou C1 and Syn 0006) varieties in their fields. In 2013, 2 villages were included in the study and the number of sorghum varieties tested increased to 4 by adding "stay green varieties" namely Seguifa and Tiandougou. These varieties remain green and available as fodder after harvesting the panicles. In the year 2014, 20 farmers from two villages, Tongo and Ngakoro, were involved in a variety test for millet and sorhum (10 farmers per crop). The tested varieties were Local boboni, Soxat, Toroniou, HKP for millet and Local kenikeni, CSM 219, Seguifa, Sangatigui for sorghum. In this study the farmer's field was divided in two parts: the first one was ploughed following contour ridges and the second one was the control. Each part included the same varieties and same cropping technics.

In each village, farmers' views were evaluated on the relevance, impact and accessibility of selected proven technologies, after they have been taken on a study tour in the villages of Tongo, Ngakoro and Djambougou where those technologies were being implemented since a couple of years. This activity, conducted in three successive years, involved 9 farmers in 2012, 7 in 2013 and 20 in 2014 per village. The feedback sessions after the study tour gathered as representative samples size, 40 peoples (farmer's trainers for each village) in 2012, 55 in 2013 and 70 in 2014. Questions and discussions were about farmers' constraints, cropping 


\section{Macrothink

systems environment, factors determining farmers' choice of (millet and sorghum) varieties and soil and water conservation technics. These discussions were supplemented with observations of tasks, events, objects in the field.

During the feedback session, discussions were informative and out of any kind of gerontocracy to respond or ask questions. For each theme discussed percentage of respondents was calculated in relation with the total number of participants.

$\% \operatorname{Resp}=\frac{\text { Nb of respondent } x 100}{\text { Total Nb of participants }}$, where Resp and $\mathrm{Nb}$ means respondents and number respectively.

Data were coded and analyzed using the Statistical Package for Social Sciences (SPSS version 20) and MS Excel software for graphics.

\section{Results}

\subsection{Farmer's Perception of Climate Change}

Climate change is described by the majority of farmers (87\%) as decrease in rainfall amount and length of rainy seasons and high increases in temperature. Ponds drying, increased deforestation, decrease in wild animals' production and productivity, increased unavailability of firewood in the surroundings, were also pointed out as facts of climate change (Figure 1).

Most of the climate change effects described relates to water issues and, technologies such as contour ridges tillage (to increase water availability to crops) and improved sorghum and millet varieties were retained for tests.

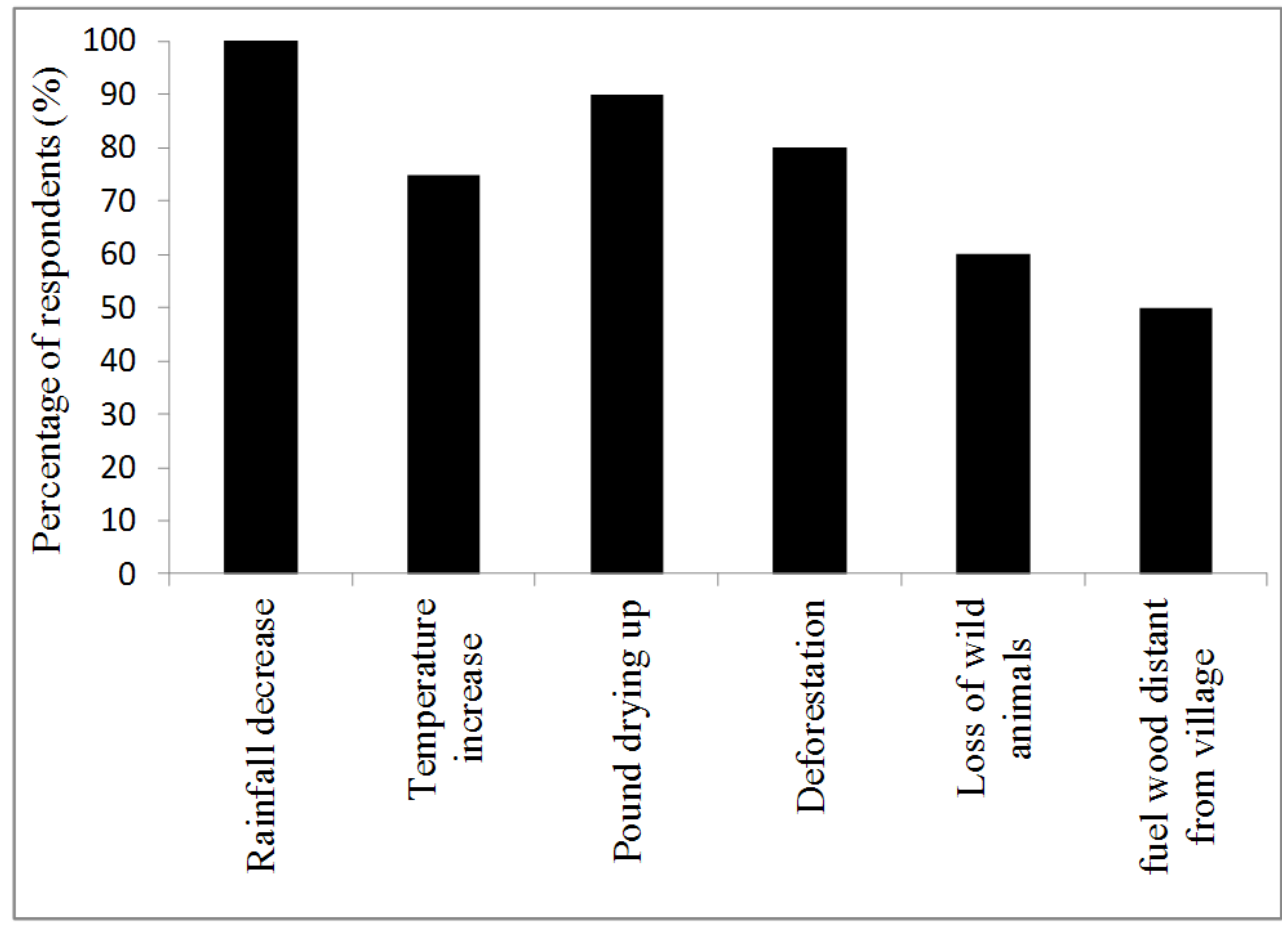

Figure 1. Farmer's perception of climate change in the rural commune of Cinzana, Mali. 


\subsection{Farmers perception /local understandings of risk and uncertainty in climate}

Unpredictability of climate was considered by $80 \%$ of respondents as major risk in the area (Figure 2). Drought and heavy rain occurrence were also mentioned as major risk for crop production and soil degradation with respectively 70 and $65 \%$ of respondents. They are followed by lack of capital $(60 \%)$ and illness $(52 \%)$. Farmers stated that drought can drastically reduce crop yield while heavy rain negatively affect soil by high runoff and erosion since soil were fragile because of few clay and organic matter to build strong structure. Lack of capital and illness were seen as medium climatic related risk. Lack of capital was not identified by farmers as a notable risk (only 3\%). In fact they explained that this constraint can be overcome by diversifying activities (trades, labor, mining etc.).

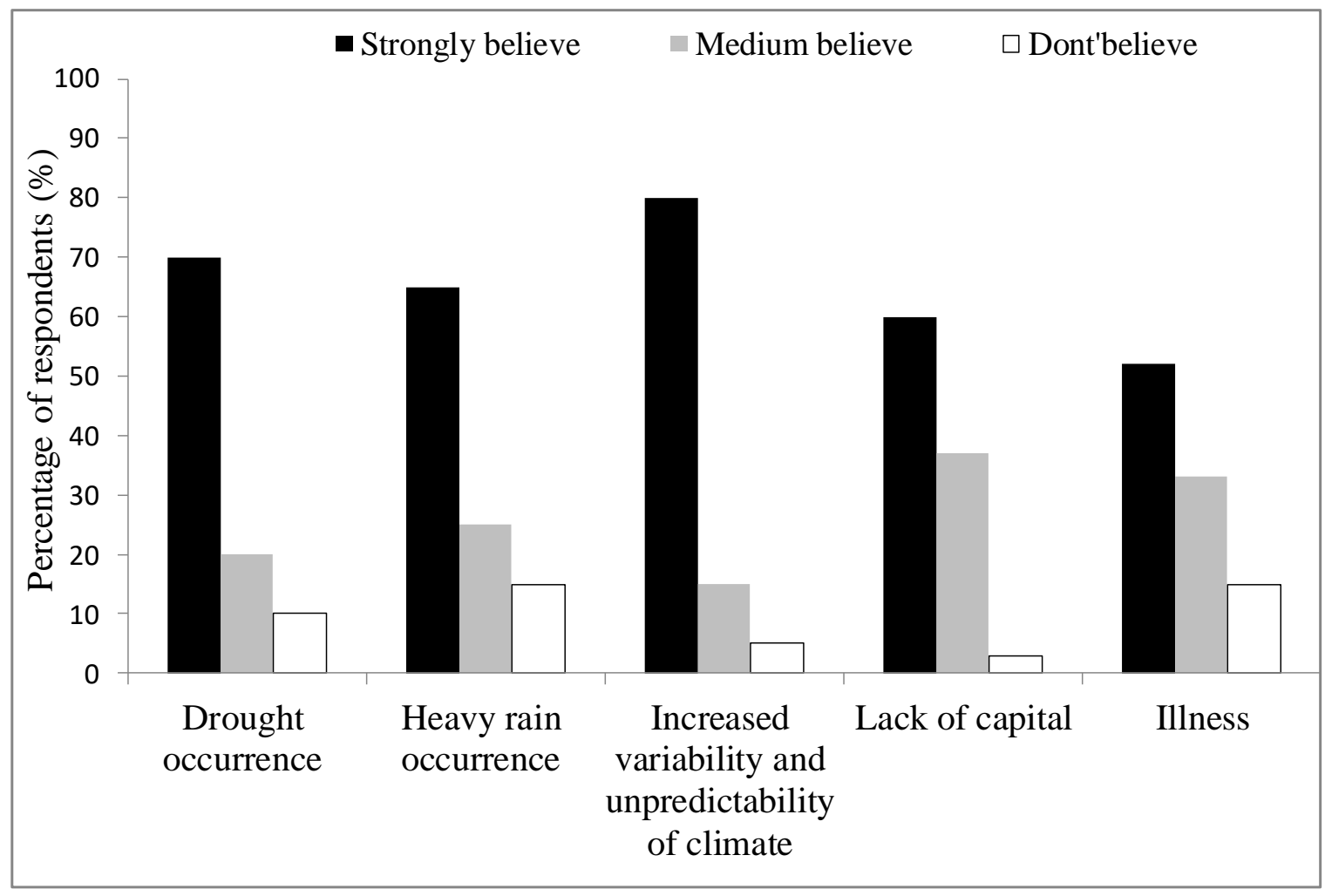

Figure 2. Farmers perception of risk and uncertainty in Sahelian climate of Cinzana

\subsection{Farmer's Perception on the Effects of Contour Ridges Tillage (CRT)}

The qualitative assessment done by farmers on the effects of CRT revealed that rain water was kept between contour ridges reducing runoff and consequently increasing infiltration in contoured plots than in the control. $70 \%$ of farmers said that humidity was still available from the first shot of hoe. This depth corresponds to $0-15 \mathrm{~cm}$ which represents the area of high density of plant roots (Figure 3). 


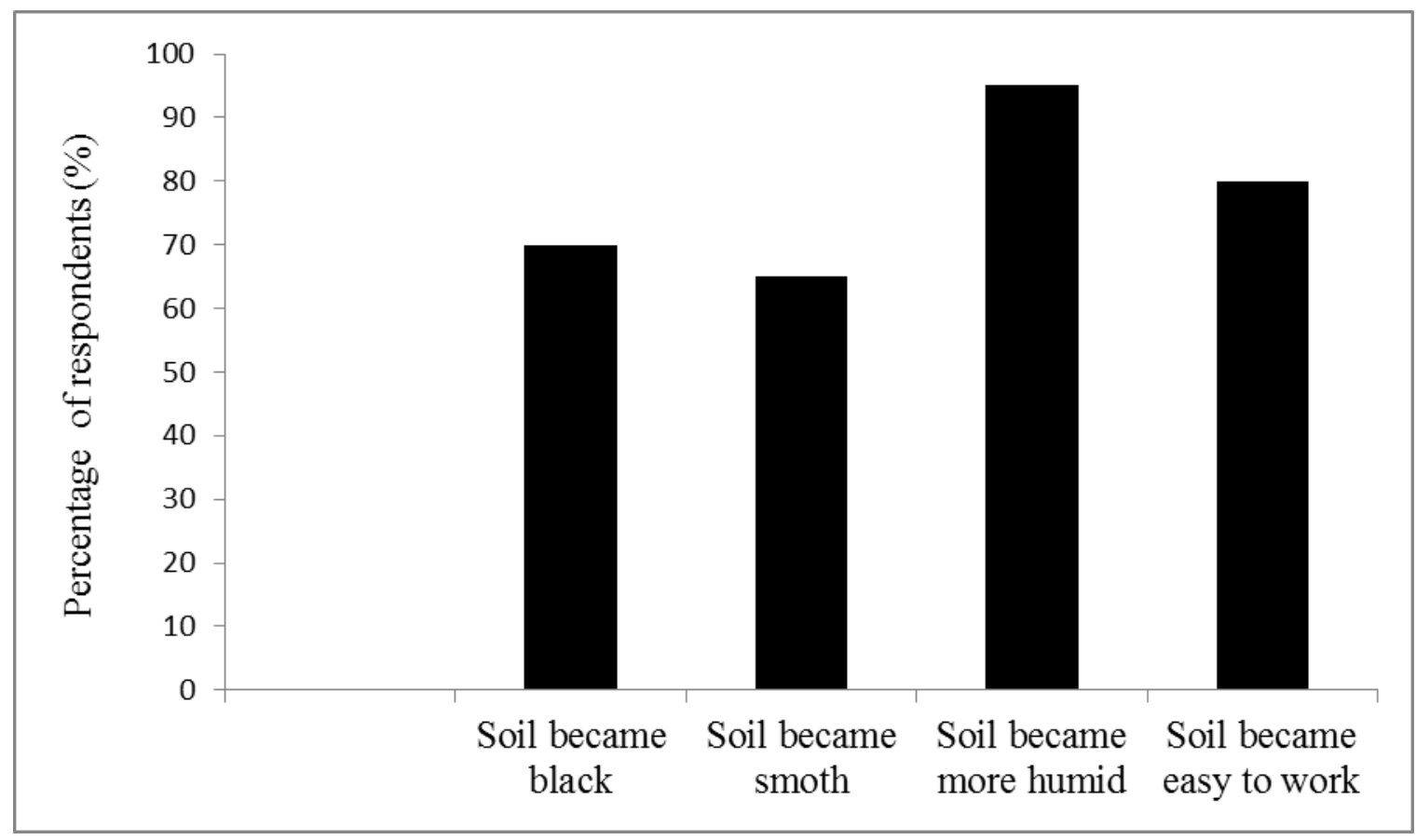

Figure 3. Opinions of farmers on the effects of contour ridging on some soil characteristics in the rural commune of Cinzana, Mali.

After farmers' study tour, $80 \%$ of the participants mentioned a better growth of plants in contoured plots where soil was more humid than in the control (Figure 2). They also observed that soil became soft and easy to work for crops maintenance operations such as mounding, weeding, fertilizer application. Also, with the use of water conservation technique, soil moisture was found to be better conserved and this allowed field operations for an extended 7 to 10 days.

Pertaining to biological effects of CRT, majority of farmers (70\% of the restitution group) reported observing many insects' galleries and earthworm populations (Figure 4). They also noted improved tree regeneration, reappearance of certain grass species which had disappeared.

With respect to CRT effect on plants' agronomic characteristics, $90 \%$ of producers, stated that two aspects retained much their attention namely, the green state of plant leaves and good appearance of panicles and grains in contoured plots compared to the control.

Producers showed higher interest when CRT technology is combined with improved varieties. Some of them had already adopted the improved varieties used in this trials, and had even shared this with others farmers from neighboring villages. These results are interesting in low or erratic rainfall year as an adaptation initiative from farmers. 


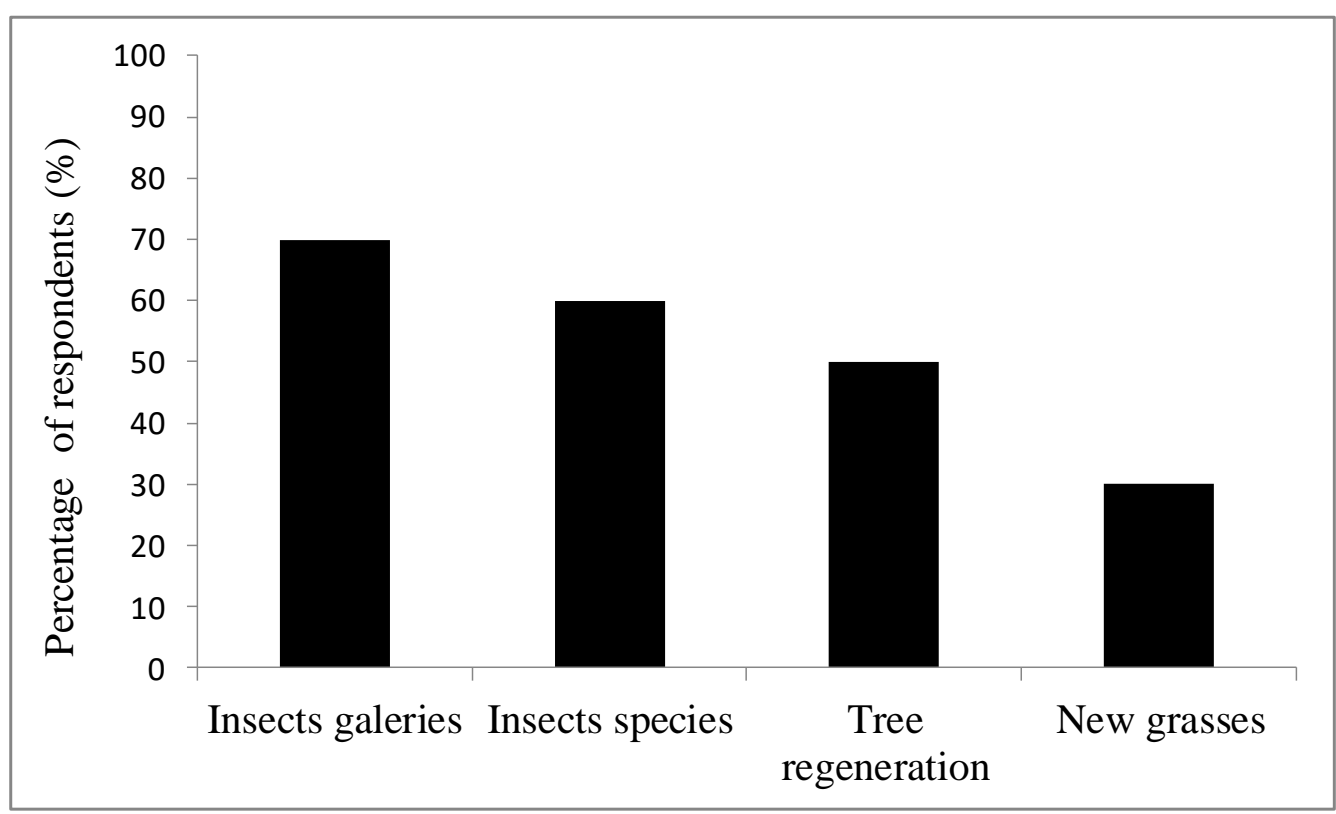

Figure 4. Farmers' perception on contour ridge tillage biological effects in the rural commune of Cinzana, Mali.

Specifically related to crops production, high density of grain in the panicles of sorghum and millet was observed in CRT plots compared to control. The use of CRT reduces runoff and erosion and allows better valorization of nutrients favorable to crop yield improvement (Figure 5).

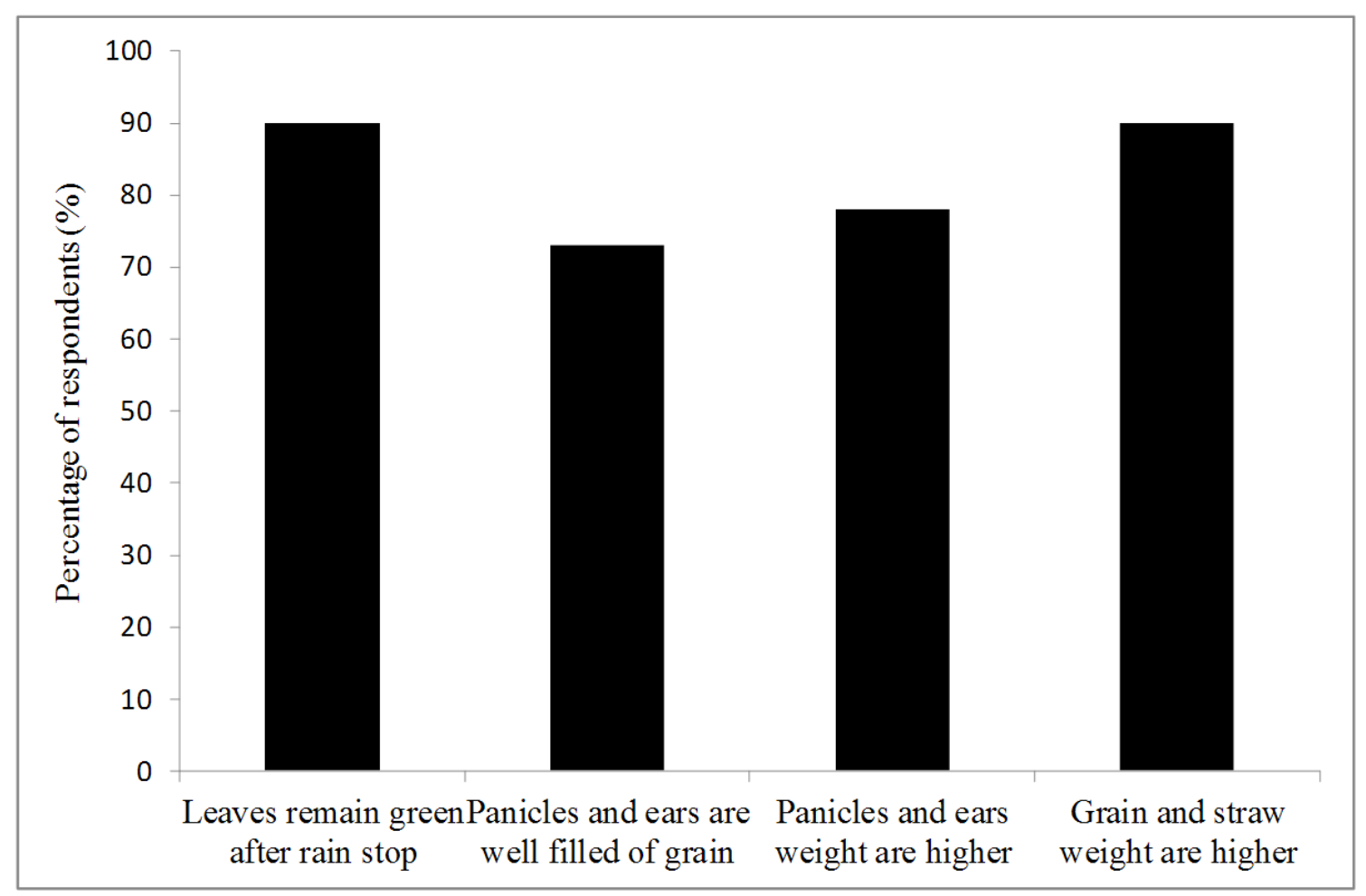

Figure 5. Farmers' perception on CRT effects on vegetative aspects and crop yields in the rural commune of Cinzana, Mali 


\section{Macrothink}

\subsection{Capacity Building}

The majority of farmers $(98.2 \%)$ request training to help them reproducing the technologies after the project life.

\subsubsection{Need of Training on CRT}

Almost all the farmers who participated to the farmers exchange visit (80\%) expressed their willing to attend a training session on a water conservation technique which for them can help securing crops production in a rainfall variability context (Figure 6). 15\% of the farmers interviewed don't know (were not clear whether they need the training or not) and 5\% don't need since they think it's the government's duty to fund and implement soil and water conservation project for farmers.

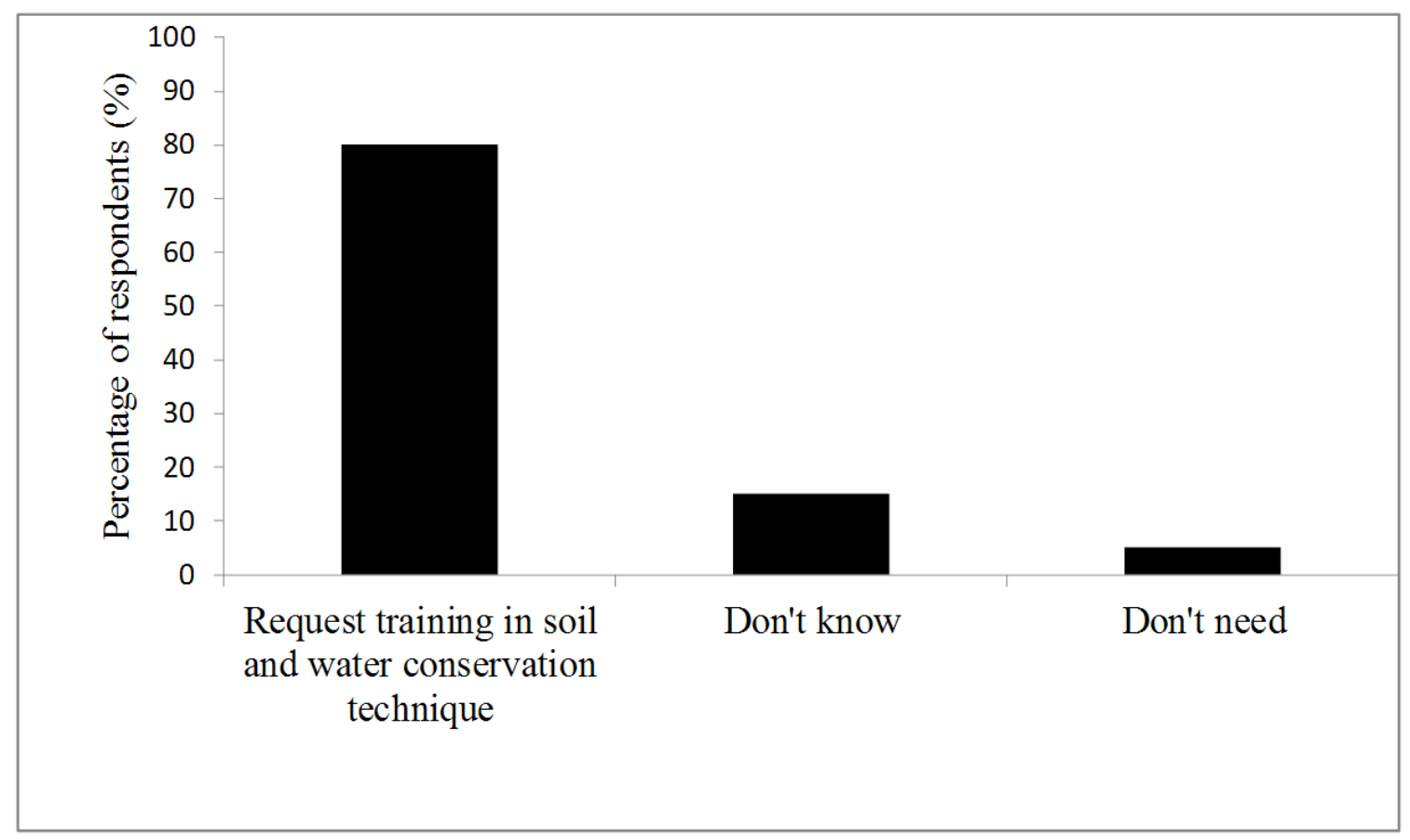

Figure 6. Opinion of farmers in training on soil and water conservation technique

Otherwise, $75 \%$ of farmers point out the necessity to obtain the required equipment which is not available on the market and accessible to them. They also, mentioned the need to follow up the farmers trained on the technique for accuracy issues (17\%) and the implication of government (8\%) to sustain the use of the technique (Figure 7).

\subsubsection{Perception on New Improved Varieties Introduced in the Area}

\subsubsection{Maturity Cycle}

More than half of the farmers (55\%) mentioned that early maturing varieties with maturity cycle comprised between 80 and 90 days were the best adapted ones in the area since nowadays the length of rainy season in the zone is about 3 months (Figure 8). About $37 \%$ of farmers stated that the reason for adopting improved varieties is because of higher yield, while resemblance to local variety and pest resistant were poorly cited as reason. They stated 


\section{Macrothink}

Journal of Agricultural Studies

ISSN 2166-0379

2017, Vol. 5, No. 1

that the varieties used since 20 years ago can no more complete their cycles in the rainy season and consequently, were abandoned. For this consideration improved early maturing varieties such as HKP, Toroniou, Synthetic006 for millet and CSM63E, Sangatigui, Djiguifa for sorghum were widely adopted in the area.

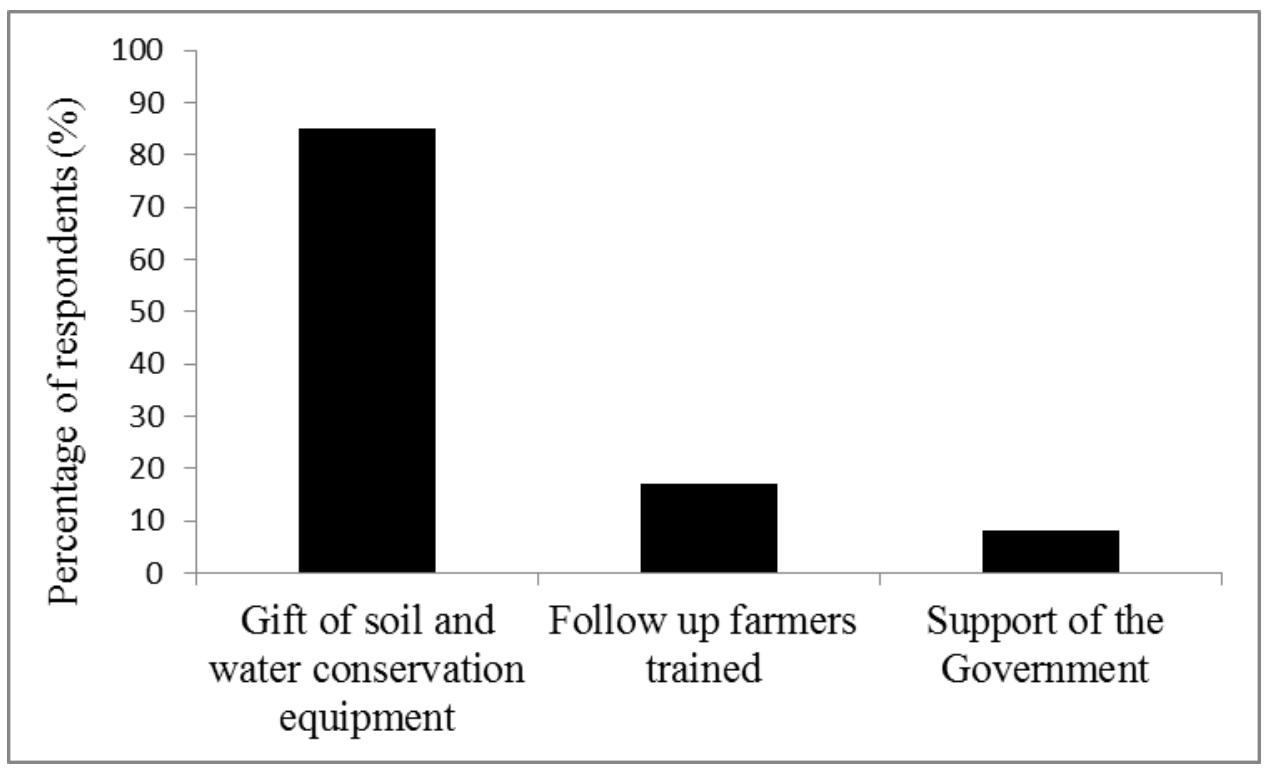

Figure 7. Opinion of farmers on adoption strategy of the soil and water conservation technique

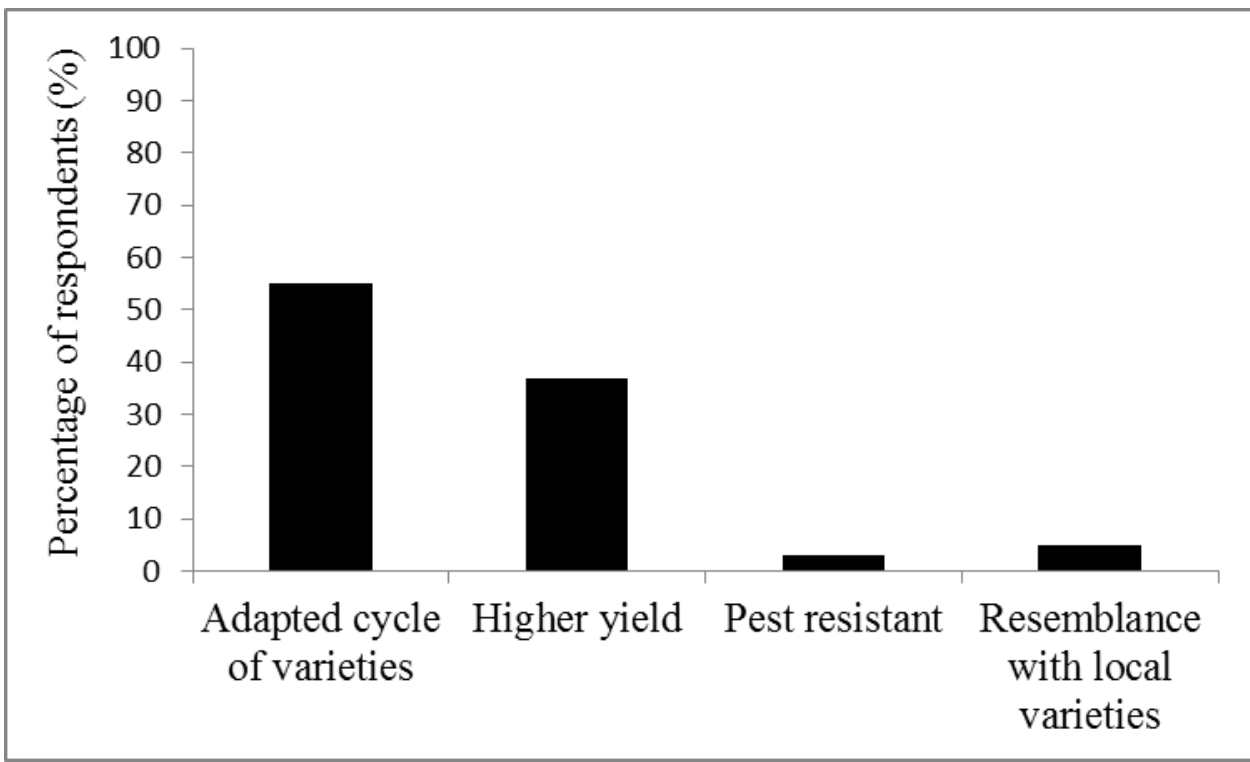

Figure 8. Opinion of farmers on the reason of adoption of improved varieties

\subsubsection{Adapted Varieties for Grain Production}

The majority of farmers opted for varieties which could still produce grain whatever the delay in sowing date was. Indeed a farmer said "very often rain variability and dry spell delay very much sowing to late in the rainy season; so we need varieties that can, despite this constrain, give good yield". About $60 \%$ of farmers thought that improved varieties should meet local 


\section{Ml Macrothink}

taste preference and the requirement of storing dishes. Varieties were also required to have good fodder quality (20\% of farmers). For this purpose the stay green Sangatigui and Synthethic 006 varieties were widely adopted in the area. The majority of farmers mentioned that panicles length (45\%) and grain color (35\%) are key elements for wide adoption since they are related to yield and acceptance by women (white color) (Figure 9).

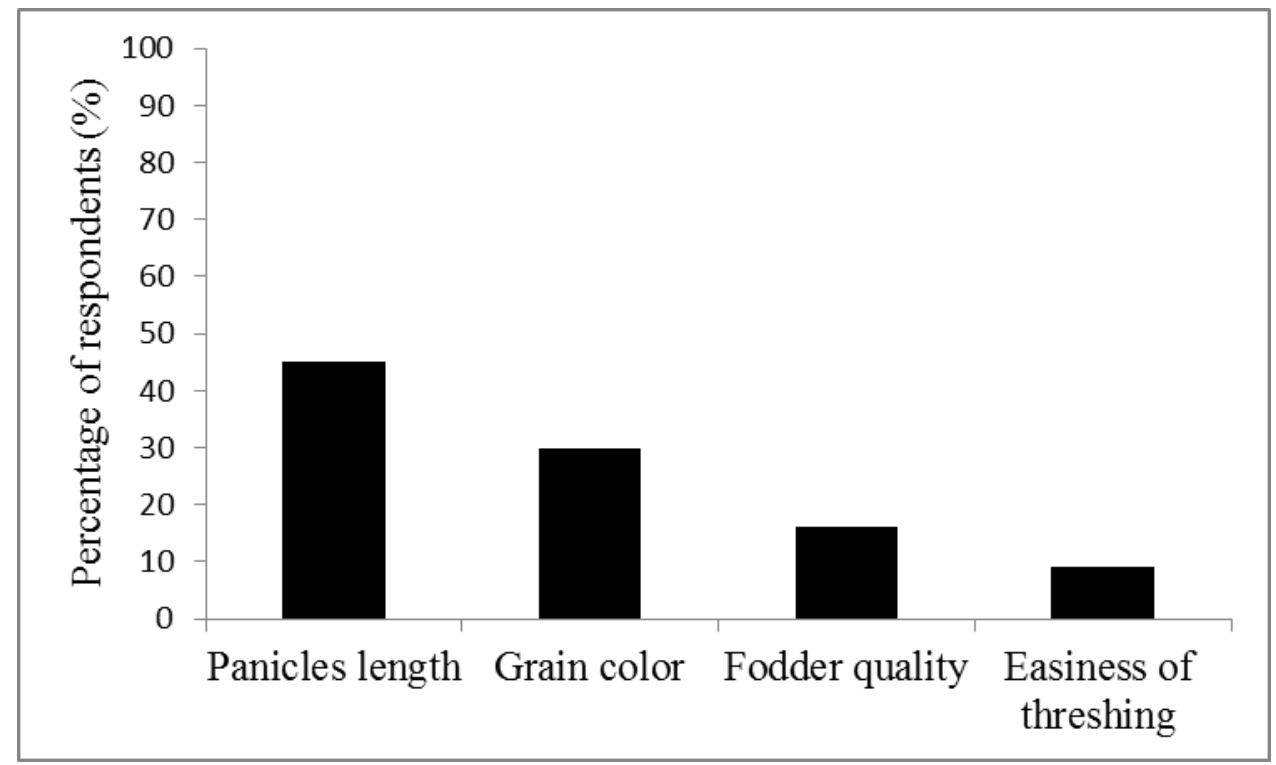

Figure 9. Key characteristics for wide adoption of improved varieties by farmers

\section{Discussions}

\subsection{Farmer's Perception of Climate Change}

Our results in this study corroborate the work by Akponikpe et al. (2010) and Onyekuru (2014) where decrease in total precipitation or change in rainfall pattern, temperature increases were pointed out as evidence of climate change. Deforestation related to human pressure, quick drying of the ponds, decreases in productivity of forest resources (animal and vegetal) were also reported as specific shifts in the sahelian area of Cinzana. These conclusions were in agreement with those of Halimatou et al. (2016) who basically reported similar trend when studying farmer's perceptions of climate change in the same area. This decrease in productivity is based on the weak resilience capacity of the smallholder farmer in Mali as also reported by Traore et al. (2013) who mentioned that farmers will be strongly impacted by $\mathrm{CC}$ because of their limited adaptive capacity related to dominant poverty in a context of subsistence farming systems.

\subsection{Farmer's Perception of Risk and Uncertainty in Climate}

The data presented illustrate that farmers of Cinzana recognize that increased variability and unpredictability of climate as well as drought and heavy rain occurrence were the greatest risks associated with crop production and constitute a challenge for them. In fact, farmers argue that very few forecasting coming from national meteorological services were available to help dealing with this global event. Anyway, coping strategies were implemented to respond to these constraints. The findings of this study are in agreement with those of 
Ogalleh et al. (2012) in his work on Local Perceptions and Responses to Climate Change and Variability in Kenya. He reported that most farmers preferred multiple options, based on adaptation practices involving diversification and use of various crop varieties. Diversification has been identified as a potential farm-level adaptation to climatic variability to face decreasing rainfall, unpredictable rainfalls, breaks in rainy seasons, early rains, late rains, etc. Sharka Juana et al. (2013) also reported that violent rain and hailstorms, low rainfall, temperature increase, higher evapo-transpiration, drought, delayed rainfall and early cessation of rain incited farmers to minimize risk by abandoning mono-cropping for mixed crop livestock systems

\subsection{Perception of Farmers on the Effects of Contour Ridges Tillage}

Soil characteristics such as dark color, softness, easiness for field operations, higher humidity, extended time laps for field operations were cited by farmers as CRT effects. Those are due to increased organic matter and water infiltration on CRT plots. These perceptions of farmers were already mentioned by Sawadogo Sawadogo (2011) who explained that farms using soil and water conservation technics show a perceptible improvement in the organic matter content of their soils as well as high vegetative cover which help reducing runoff and erosion, and leading to yield improvements.

\subsection{Biological Activity}

Appearance of several insect and plant species on CRT plots could be due to the improvement of soil physico-chemical characteristics. Similarly, in Ethiopia, Gebremichael et al. (2015) reported that doing mulching on contour line accelerate biomass decomposition, increase soil fertility and consequently improve biological activities.

\subsection{Vegetative Aspects and Crop Yields}

The use of CRT leads to better water conservation, longer soil moisture, longer green leaves period even after the rain stop, better panicles filling since water is the main factor impacting directly crop growth. Our findings corroborate the work of Traore (2003) and Junge et al. (2009) where farmers had a positive impression of the effectiveness of water conservation technics as erosion control measures and, also mentioned additional advantages, such as the increased soil fertility from the decomposition of organic material and the release of nutrients. They also found that contour tillage was accepted as a compatible methodology that was easy and cheap to adopt and to practice, as the equipment to perform it, was available.

\subsection{Capacity Building}

Farmers requested training on water conservation technics which will improve water availability to plants and therefore improve performance. Because this was a request from farmers themselves, we believe adoption at wider scale will be easy. This perception of farmers is in straight line with what was reported by Junge and al. (2009) who explained that to strengthen farmers' capacities on innovations/technologies, frequent contact of farmers with extensionists, as well as membership in agricultural cooperatives as source of information on new technologies are necessary. He also advised farmers' exchange visits as a 
practical mean for training and adoption of the technology but it required sufficient funds to provide transportation of the agents to the villages and equipment for the training sessions.

\subsection{Perception on New Improved Varieties Introduced in the Area}

Despite drought, farmers' varieties still dominate in systems as they adapt to random culture conditions (Coulibaly, 2011). However, several improved varieties were also tested in the area by farmers with great satisfaction and they even had already adopted the improved varieties that were more productive and had approximately the same taste as local varieties.

This situation of farmers being open to changes, is known through the report from Coulibaly (2011) who explained that farmer's priority is food self-sufficiency and consequently he undertake changes in his cropping system while keeping his total area enough to meet his objectives.

Generally, farmers adapt to $\mathrm{CC}$ by adopting new early maturing varieties, using intercropping, adjusting cropping calendar and adopting varieties suitable for local diet, etc. These results are supported by Comoé (2013) studying the contribution of farmers to food security in Côte d'Ivoire. He reported several farmer strategies based on sowing management, change in technical itinerary including crops association, adoption of short-season varieties, a decrease in the number of cattle to have enough grass available during dry spells, change in diet by eating more cassava or maize although they still prefer their staple foods, rice and yams.

\section{Conclusion}

The highly variable climate of the region constitutes an important constraint for agricultural strategies which, so far, were not able to meet the expected rural development goals. Farmers perceived climate change through indicators such as strong decreases in rainfall amount and pattern (length of rainfall and rainy seasons), high increases in temperature, deforestation, ponds drying, reduction of fuelwood collection area. They also were clear about some climate related risks for agriculture and gave their views on soil and water conservation technologies and improved varieties. Diversification of adaptation measures to match the environmental reality appeared as a strong requirement. Strengthening farmers' capacity on innovations, through for instance, extension agents and farmers exchanges visits were practical means for acceleration and wide adoption of proven risk management technologies such as adapted improved millet and sorghum varieties. This strategy needs to be complemented with training on specific technologies for agriculture soil and water management.

\section{Acknowledgement}

This work was funded by the CGIAR (Consultative Group on International Agricultural Research) Research Program on Climate Change, Agriculture and Food Security (CCAFS), which is a strategic partnership of the CGIAR and Future Earth. The CCAFS Program is carried out with funding by CGIAR Fund Donors, the Canadian International Development Agency (CIDA), the Danish International Development Agency (DANIDA), and the European Union (EU); with technical support from the International Fund for Agricultural 
Development (IFAD). The world Agroforestry Centre (ICRAF) is also acknowledged for coordinating the participatory action research on climate smart agriculture (PAR-CSA) in West Africa. Additional funding from the Institut d'Economie Rurale du Mali is also, gratefully acknowledged. We are grateful to AMEDD (Association Malienne d'Eveil au Developpement Durable) and ARCAD (Association pour le Renforcement des Capacités pour une Agriculture Durable) NGOs (Non-Governmental Organization) for supporting farmer exchange visit in the PAR site. We are grateful to farmers of Nkakoro, Tongo, Sorobougou, Moussawèrè and Dougakoungo. We thank a lot Youssouf Coulibaly (extension agent in Cinzana) and Oudou Cissé (technician of the project) for facilitating the implementation of research activities and data collection.

\section{References}

Akponikpe, P., Johnston, P., \& Agbossou, E. K. (2010). Farmers' perceptions of climate change and adaptation strategies in sub-Sahara West Africa. 2nd International Conference on Climate, Sustainability and Development in Arid Regions, Fartaleza-Ceara, Brazil. https://scholar.google.co.za/citations?view_op=view_citation\&hl=en\&user=iplGNaYAAAAJ \&citation_for_view=iplGNaYAAAAJ:u-x6o8ySG0sC

Bationo, A., \& Buerkert, A. (2001). Soil Organic carbon measurement for sustainable land use in Sudano-Sahelian West Africa. Nutrient Cyclying in Agroecosystems;61:131-42. http://citeseerx.ist.psu.edu/viewdoc/download?doi=10.1.1.519.7138\&rep=rep1\&type=pdf

Bayala, J., Sileshi, G. W., Coe, R., Kalinganire, A., Tchoundjeu, Z., \& Sinclair, F. (2012). Cereal yield response to conservation agriculture practices in drylands of West Africa: a quantitative synthesis. Journal of Arid Environments, 78(13-25). http://planetaryhealthalliance.org/publications/cereal-yield-response-conservation-agriculture -practices-drylands-west-africa

Comoé, H. D. N. (2013). Contribution to food security by improving farmers' responses to climate change in northern and central areas of Côte d'Ivoire. Degree of doctor of sciences $\begin{array}{llllll}\text { ETH Zurich NO } & \text { DTH } & \text { 21244, } & 130 & \text { p. }\end{array}$ e-collection.library.ethz.ch/eserv/eth:7137/eth-7137-01.pdf

Coulibaly, H. (2011). Role des organisations paysannes dans la diffusion de semences de céréales : articulation des réseaux semenciers étatiques et traditionnels paysans pour une conservation in situ des variétés. Le cas des mils et sorghos au Mali. Thèse de Doctorat en géographie humaine, économique et régionale de l'université de Paris ouest Nanterre, France. 295 p. ur-green.cirad.fr/content/download/4429/33213/version/1/file/Thèsefinale.pdf

Doumbia, M, Jarju, A., Sene, M., Traore, K., Yost, R., \& Kablan, R. (2008). Sequestration of organic carbon in West African soils by Aménagement en Courbes de Niveau. Agronomy for Sustainable Development. 29:267-75. http://dx.doi.org/10.1051/agro:2008041

Ejeta, G., Hassen, M. M., Mertz, E. T. (1987). In vitro digestibility and amino acid composition of pearl millet (Pennisetum typhoides) and other cereals. Proc Natl Acad Sci USA Vol 84, pp 6016-6019, September 1987 Applied Biology. 
https://www.ncbi.nlm.nih.gov/pmc/articles/PMC298998/pdf/pnas00332-0012.pdf

FAOSTAT. (2008). Food and Agriculture Organization of the United Nations, FAOSTAT database. Available at:

http://faostat.fao.org/site/362/DesktopDefault.aspx?PageID=362.(September 26, 2016).

Gebremichael, A., Yakob, G., \& Mekonnen, G. (2015). Assessment of farmers' perception and adaptation mechanism to soil erosion problem in ShombaKichib, Gimbo District, Kaffa Zone, South West Ethiopia. African Journal of Agricultural Research, 10(27), 2608-16. http://dx.doi.org/10.5897/AJAR2014.9404

Gigou, J., Traore, K., Giraudy, F., Coulibaly, H., Sogoba, B., \& Doumbia, M. (2006). Aménagement paysan des terres et réduction du ruissellement dans les savanes africaines. Cah Agric, 1(15), 116-22.

http://revues.cirad.fr/index.php/cahiers-agricultures/article/view/30569

Goudou, D., Traoré-Gue, J. N., Ouedraogo, M., Segda, Z., Diakité, L., \& Kebe, Z. (2012). Village Baseline Study - Site Analysis Report for Segou - Cinzana, Mali (MA0109). CGIAR Research Program on Climate Change, Agriculture and Food Security (CCAFS), Copenhagen, Denmark. Available online at: wwwccafscgiarorg (October 8, 2016).

IPCC "Climate Change. (2007). Impacts, Adaptation and Vulnerability. Contribution of Working Group II to the Fourth Assessment Report of the Intergovernmental Panel on Climate Change." M.L. Parry, O.F. Canziani, J.P. Palutikof, P.J. van der Linden and C.E. Hanson, Eds., Cambridge University Press, Cambridge, UK, pp.976. https://www.ipcc.ch/publications_and_data/ar4/wg2/en/spm.html

Junge, B., Deji, O., Abaidoo, R., Chikoye, D., \& Stahr, K. (2009). Farmers' Adoption of Soil Conservation Technologies: A Case Study from Osun State, Nigeria. The Journal of Agricultural Education and Extension, 15(3), 257-74.

http://dx.doi.org/10.1080/13892240903069769

Kemausuor, F., Dwamena, E., Bart-Plange, A., \& Kyei-Baffour, N. (2011). Farmers' Perception Of Climate Change In The Ejura-Sekyedumase District Of Ghana. Journal Of Agricultural And Biological Science, 6(10).

http//www.arpnjournals.com/jabs/research.../rp.../jabs_1011_321.pdf

Macauley, H., \& Tabo, R. (2015). Cereal Crops: Rice, Maize, Millet, Sorghum, Wheat. An Action Plan for African Agricltural Transformation. Feeding Africa -Background paper, 36p..

Masters, G., Norgrove, L. (2010). Climate change and invasive alien species. CABI Working Paper 1, 30 pp.

http://www.cabi.org/Uploads/CABI/expertise/invasive-alien-species-working-paper.pdf

Nellemann, C., McDevette, M., Manders, T., Eickhout, B., Prins, A., \& Kalterborn, B. (2009).The environmental food crisis. The environment's role in averting future food crises. A UNEP rapid response assessment. Arendal, UNDP. http://www.grida.no/files/publications/FoodCrisis_lores.pdf 


\section{MInstitute Macrothink $_{\text {Int }}$}

Journal of Agricultural Studies ISSN 2166-0379

Ogalleh, S. A., Vogl, C. R., Eitzinger, J., \& Hauser, M. (2012). Local Perceptions and Responses to Climate Change and Variability: The Case of Laikipia District, Kenya. Sustainability, 4, 3302-25. http://dx.doi.org/10.3390/su4123302

Onyekuru, N. A. (2014). Assessing Climate Change Impacts and Indigenous Adaptation Strategies on Forest Resource Use in Nigeria. PhD thesis University of York, Environment Department, 294pp. http://etheses.whiterose.ac.uk/9298/

PROMISAM. (2007). Plan de Securite Alimentaire Commune Rurale de Cinzana. 2007- 2011, USAID, mars 2007, 16 p. Projet de Mobilisation des Initiatives en matière de Sécurité Alimentaire au Mali (PROMISAM).

csa.gouv.ml/plans/Segou/plansa_segou/P_S_A_Cinzana.pdf

Sanfo, S, Lamber, J. P. A., Mueller, M., \& Fonta, W. (2014). Farmers' Perceptions Of Climate Change And Climate Variability Versus Climatic Evidence In Burkina Faso, West Africa. Conference: Climate Change In Africa Negotiations, Translations, And Socio-Political Implications 10th - 12th September 2014, Center For Development Research (ZEF), Bonn, Germany, At Bonn, Germany.

Sawadogo, H. (2011). Using soil and water conservation techniques to rehabilitate degraded lands in northwestern Burkina Faso. International Journal of Agricultural Sustainability, 9(1), 120-8. http://dx.doi.org/10.3763/ijas.2010.0552

Sharka Juana, J., Kahaka, Z., \& Okurut, F. N. (2013). Farmers' Perceptions and Adaptations to Climate Change in Sub-Sahara Africa: A Synthesis of Empirical Studies and Implications for Public Policy in African Agriculture. Journal of Agricultural Science, 5(4). http://dx.doi.org/10.5539/jas.v5n4p121

SSAC. (2014). Rapport annuel, Sous-Secteur d'Agriculture de Cinzana, Région de Ségou, Mali, 25 p.

Tacko Kandji, S, Verchot, L, \& Mackensen, J. (2006). Climate Change and Variability in the Sahel Region: Impacts and Adaptation Strategies in the Agricultural Sector. UNEP \& ICRAF, 48pp.

http://www.the-eis.com/data/literature/Climate_change_and_variability_in_the_southern_afri ca.pdf

Traore, K. (2003). Le parc à karité, sa contribution à la durabilité de l'agrosystème: cas d'une toposéquence à Konobougou dans le Mali-sud. Thèse de Doctorat en Sciences du Sol Université de Montpellier II, ENSAM, France. 2003:180 p.

Traore, B., Corbeels, M., Van Wijk, M. T., Rufino, M. C., \& Giller, K. E. (2014). Effects Of Climate Variability And Climate Change On Crop Production In Southern Mali. European Journal Of Agronomy, 49, 115- 25.

WDI. (2006). World Development Indicators (WDI) Available: http://devdata.worldbank.org/wdi2006/content/index2.htm. (September 14, 2016)

Zougmoré, R., Jalloh, A., \& Tioro, A. (2014). Climate-smart soil water and nutrient 


\section{Macrothink}

Journal of Agricultural Studies

ISSN 2166-0379 2017, Vol. 5, No. 1

management options in semiarid West Africa: a review of evidence and analysis of stone bunds and zaï techniques. Agriculture and Food Security, http://wwwagricultureandfoodsecuritycom/content/3/1/16. (October 24, 2016)

\section{Copyright Disclaimer}

Copyright for this article is retained by the author(s), with first publication rights granted to the journal.

This is an open-access article distributed under the terms and conditions of the Creative Commons Attribution license (http://creativecommons.org/licenses/by/4.0/). 